Full-text Available Online at www.ajol.info and www.bioline.org.br/ja
J. Appl. Sci. Environ. Manage. Dec., 2015

Vol. 19 (4) 687 - 693

\title{
Antimicrobial Potency of Hydro, acetone and Ethanolic extracts of Treculia africana Decne Root and Stem Bark
}

\section{${ }^{* 1}$ OYEYIPO, O. OLAITAN; ${ }^{2}$ ONASOGA; M. FUNMILAYO}

\author{
1Department of Microbiology (Medical Microbiology Unit), University of Ilorin, Kwara State, Nigeria \\ 2Department of Biological Sciences (Microbiology Unit), Oduduwa University, Osun State, Nigeria \\ e-mails: mails4tim1@yahoo.com, funmilayo4live@yahoo.com
}

\begin{abstract}
Treculia africana is a plant that is used in traditional medicine for the treatment of diverse ailments. To investigate the scientific basis for the use of the plant, the antimicrobial activities/potency of the root and stem bark extracts were evaluated against common gram negative and gram positive bacteria as well as yeast. The chemical constituents of the plant in addition to the effect of temperature and $\mathrm{pH}$ on its antimicrobial potencies were investigated. The phytochemical constituents of the dried powdered plant parts were extracted using aqueous and organic solvents (acetone and ethanol). The antimicrobial activity of the concentrated extracts was evaluated by determining the diameter of zone of inhibition against both gram negative and gram positive bacteria and yeast, using the disc diffusion technique. Phytochemical studies revealed the presence of glycosides, anthraquinone, free aglycone, saponin, steroids and polyphenols. The extracts were active against both gram positive and gram negative bacteria. The activities of the plant extracts were not affected at varied temperatures $\left(4^{\circ} \mathrm{C}, 30^{\circ} \mathrm{C}, 60^{\circ} \mathrm{C}\right.$ and $100^{\circ} \mathrm{C}$ ), but decreased at alkaline $\mathrm{pH}$. Minimum inhibitory concentration (MIC) and minimum bactericidal concentration (MBC) of the extracts on the test organisms revealed lowest MIC and MBC against Salmonella paratyphi, Salmonella typhi and Bacillus subtilis with highest MIC and MBC exhibited against Staphylococcus aureus. Generally, there was significant difference $(\mathrm{p}<0.05)$ in the antimicrobial activities of the test extracts and control antibiotics, with the control antibiotics exerting broader antimicrobial activity. Treculia africana demonstrated broad spectrum antibacterial activity and a potential source of new classes of antibiotics that could be useful for infectious disease chemotherapy and control. @ JASEM
\end{abstract}

http://dx.doi.org/10.4314/jasem.v19i4.17

KEY WORDS: Treculia africana, Underutilized plant, Antimicrobial potency, MIC, MBC, Phytochemicals

There is increasing incidence of multiple antibiotic resistances in microorganisms in recent years, majorly due to indiscriminate use of commercial antibacterial drugs commonly administered in the treatment of infectious diseases. Over the past decades, researchers have turned back to traditional folk medicines or natural products to unveil the scientific basis of remedial effects such as antimicrobial agents. Plants remain the most common source of antimicrobial agents. Their usage as traditional health remedies is the most popular for $80 \%$ of world population in Asia, Latin America and Africa and is reported to have little or no side effects (Oyeyipo, 2011). Recently, the pharmaceutical industries have invested a lot of resources in developing natural products derived from plants, to manufacture more cost effective remedies that are affordable to the populace. This increasing incidence of multidrug resistance amongst pathogenic microbes has further necessitated the need to research for newer antimicrobial sources.
African breadfruit (Treculia africana) is a member of the family moracea; it is indigenous, popularly called 'Ukwa' and widely grown in the southern states of Nigeria for its nutritive/food value but under-utilized (Oyeyipo, 2011; Oyeyipo et al., 2012; Njoku et al., 2013). The seeds have been found to contain high quality protein $(17.5 \%)$, fat $(2.3 \%)$, Carbohydrate (73\%) (Oyeyipo, 2011). Treculia africana Decne (Moraceae) is among the several tropical African plants with ethnomedicinal and nutritive value, having the potential to provide important means or leads for a rational treatment and management of diabetes in tropical African countries. Treculia africana is reported to be an important component of one of the ancient anti-diabetic recipe used in the Western and Middle Belt of Nigeria (Oyelola et al., 2007). The antibacterial effect of the stem bark extract on gastrointestinal (GIT) pathogens has been reported (Ogbonnia et al., 2008). We have published a series of work on the nutritional value of the plant (Oyeyipo, 
2011; Oyeyipo et al., 2012; Oyeyipo et al., 2012; Njoku et al., 2013).

This study therefore investigated the antimicrobial potency of the plant and also evaluated the effect of temperature and $\mathrm{pH}$ on the efficacy of the plant as an antimicrobial agent. This research work is one in a series of steps aimed at enhancing the utilization of the plant.

\section{MATERIALS AND METHODS}

Source of roots and stem bark: Plant materials (roots and stem bark) of Treculia africana were collected from the wild in Obite II, Etche Local Government Area of Rivers State, Nigeria and identified and authenticated at the Department of Plant Science and Biotechnology, University of Port Harcourt, Rivers State, Nigeria.

Preparation of extracts: This was carried out as earlier described with slight modifications (Predrag et al., 2005). The freshly collected roots and stem bark were chopped into pieces and shade dried at room temperature $\left(32-35^{\circ} \mathrm{C}\right)$ to constant weight for 5 days. $50 \mathrm{~g}$ of each plant parts were coarsely powdered using a mortar and pestle and were further reduced to powder using an electric blender. The powder was transferred into closed containers. Each of the powdered air-dried plant material was extracted with water, acetone and ethanol. $25 \mathrm{~g}$ of each powdered sample was mixed in a conical flask with $100 \mathrm{ml}$ of deionized, distilled water or organic solvent, plugged, then shaken at $120 \mathrm{rpm}$ for 30 minutes and kept for 24 hours. After 24 hours, each of the extracts was filtered rapidly through four layers of gauge and then by a more delicate filtration through Whatman no1 filter paper. The resulting filtrates were then concentrated in a rotary evaporator and subsequently lyophilized to dryness. The yield of powder was $48 \%$ from water extracts, $34 \%$ from acetone and $21 \%$ from ethanol extracts for the root while $51 \%, 32 \%$ and $19 \%(\mathrm{w} / \mathrm{w})$ were obtained for the stem bark, respectively.

Source of test organisms: Bacterial isolates which included Escherichia coli, Proteus mirabilis, Pseudomonas aeruginosa, Salmonella typhi, Salmonella paratyphi, Klebsiella spp. for gram negative bacteria and Staphylococcus aureus, Bacillus subtilis and Streptococcus pyogenes for gram positive bacteria, were clinical isolates obtained from the Medical Microbiology Laboratory of the University of Ilorin Teaching Hospital, Kwara State, Nigeria, while the yeast isolates used, Candida albicans, was laboratory isolates obtained from the special pathogen Laboratory of the University of Ilorin Teaching Hospital. All the bacterial strains were suspended in nutrient broth and incubated at $37^{\circ} \mathrm{C}$ for 48 hours.

Phytochemical evaluation of the crude extracts: The phytochemical screening was conducted by previously described methods of Farnsworth (1966), Eaton (1989), Silva et al. (1993), Harborne (1998) and Houghton and Raman(1998).

For Alkaloids detection, the extracts $(1.0 \mathrm{~g})$ was dissolved in $10 \mathrm{~mL}$ purified water and filtered. To 5 $\mathrm{mL}$ of the filtrate, $2 \mathrm{~mL}$ of $10 \% \mathrm{HCl}$ were added and boiled in a water bath for about $3 \mathrm{~min}$. To $2 \mathrm{~mL}$ of the alkaloid salt solution, 3 drops of Mayer's reagent or Dragendorff's reagent were added.

For Carbohydrates, the Molisch test was used for all monosaccharide and Fehling's solutions (I and II) test was used for detection of all reducing sugars (Eaton, 1989).

Cardiac glycosides were tested using Legal test and Kedde test for the detection of the presence of lactone ring and the Killer-Kiliani test for the detection of the presence of deoxysugar (Farnsworth,1966).

Cyanogenic glycosides were identified by suspending $0.5 \mathrm{~g}$ extract in $10 \mathrm{~mL}$ sterile water, and filtered. Sodium picrate paper was added to the filtrate and heated to boil.

The extracts were also tested for free aglycone, and also for the bonded anthraquinones aglycone in the glycoside. Five grams of the extract was added to 10 $\mathrm{mL}$ of water, boiled and filtered and allowed to cool. Then $2 \mathrm{~mL}$ of the filtrate was shaken with $5 \mathrm{~mL}$ of chloroform. The chloroform layer separated and concentrated to about $2 \mathrm{~mL}$ and $2-3 \mathrm{~mL}$ ammonia solution added. The bonded aglycone was tested using modified Börntrager's test Houghton and Raman (1998).

For saponins, the extracts were subjected to frothing test for the identification of saponin. Haemolysis test was further performed on the frothed extract in water to remove false positive results. Steroidal and triterpenes saponins were distinguished using the Liebermann-Burchard test (Farnsworth, 1966).

The presence of flavonoids was determined using magnesium powder and a few drops of $\mathrm{HCl}$ test (Silva et al., 1993).

Determination of antimicrobial activity: Antimicrobial activity of the aqueous and organic extracts of the plant sample was evaluated by the disc diffusion method (Aida et al., 2001). For determination of antibacterial activity, bacterial cultures were adjusted to $0.5 \mathrm{McFarland}$ turbidity standard and inoculated 
onto Mueller Hinton Agar plates (diameter: $15 \mathrm{~cm}$ ). For the determination of antimycotic activity, all the Candida albicans was first adjusted to the concentration of $10^{6} \mathrm{cfu} / \mathrm{ml}$. Culture of Candida albicans was then suspended in sterile solution of $0.9 \%$ normal saline and inoculated onto Saboraud Dextrose Agar plates. Sterile filter paper discs (diameter $6 \mathrm{~mm}$ for bacteria and $13 \mathrm{~mm}$ for yeast) impregnated with $100 \mu \mathrm{l}$ of extract dilutions reconstituted in minimum amount of solvent at concentrations of 50 and $100 \mathrm{mg} / \mathrm{ml}$ were applied over each of the culture plates previously seeded with the $0.5 \mathrm{McF}$ arland and $10^{6} \mathrm{cfu} / \mathrm{ml}$ cultures of bacteria and yeast respectively. Bacterial cultures and that of Candida albicans were then incubated at $37^{\circ} \mathrm{C}$ for 18 hours. Paper discs impregnated with $20 \mu \mathrm{l}$ of a solution of $10 \mathrm{mg} / \mathrm{ml}$ of ciprofloxacin and cotrimoxazole (for bacteria) and nystatin and amphotericin B (for yeast) as standard antimicrobials were used as control. Antimicrobial activity was evaluated by measurement of zone of inhibition around each paper disc. For each extract duplicate trials were conducted against each organism.

Determination of $M I C$ and $M B C$ : The minimum inhibitory concentration (MIC) of the extracts was estimated for each of the test organisms in triplicates. To $0.5 \mathrm{ml}$ of varying concentrations of the extracts (20.0, 18.0, 15.0, 10.0, 8.0, 5.0, $1.00 .5,0.05$ and $0.005 \mathrm{mg} / \mathrm{ml}), 2 \mathrm{ml}$ of nutrient broth was added and then a loopful of the test organism previously diluted to $0.5 \mathrm{McFarland}$ turbidity standard for (bacterial isolates) and $10^{6} \mathrm{cfu} / \mathrm{ml}$ (for yeast isolates) were introduced into the tubes. The procedure was repeated on the test organisms using the standard antimicrobials (ciprofloxacin, cotrimoxazole, for bacteria and nystatin and amphoteracin B, for yeast). A tube containing nutrient broth only was inoculated with the test organisms as described above which served as control. Tubes containing bacterial cultures were then incubated at $37^{\circ} \mathrm{C}$ for 24 hours while tubes containing yeast spores were incubated for 48 hours at room temperature $\left(30-32^{\circ} \mathrm{C}\right)$. Following incubation the tubes were examined for microbial growth by observing for turbidity.

To determine the MBC, from each set of test tubes showing no growth during the MIC determination, a loopful of broth was collected and inoculated on sterile nutrient agar (for bacteria) and saboraud dextrose agar (for yeast) by streaking. Nutrient agar and saboraud agar only were streaked with the test organisms respectively to serve as control. Plates inoculated with bacteria were incubated at $37^{\circ} \mathrm{C}$ for 24 hours while those inoculated with yeast were incubated at room temperature $\left(30-32^{\circ} \mathrm{C}\right)$ for 48 hours. After incubation the concentration at which there was no visible growth was noted as the minimum bactericidal concentration.

Effect of Temperature and $p H$ on antimicrobial activity of extracts: Five milliliters of $100 \mathrm{mg} / \mathrm{ml}$ of acetone extracts were constituted in test tubes and treated at 4, 30, 60 and $100^{\circ} \mathrm{C}$ in a water bath for 30 minutes and tested for antimicrobial activity. To determine the effect of $\mathrm{pH}$, acetone extracts were treated at $\mathrm{pH}$ ranges of 2.5 to $10 \mathrm{using} 1 \mathrm{~N} \mathrm{HCl}$ and $1 \mathrm{~N}$ $\mathrm{NaOH}$ solutions respectively in series of test tubes for 30minutes. After 30 minutes of treatment, each of the treated extracts were neutralized $(\mathrm{pH} 7)$ using $1 \mathrm{~N} \mathrm{HCl}$ and $1 \mathrm{~N} \mathrm{NaOH}$ as the case may be, and then tested for antimicrobial activity.

Statistical analysis: The results were expressed as mean \pm standard deviation and the test doses compared with the control by analysis of variance (ANOVA). Differences were considered significant if $\mathrm{p}<0.05$.

\section{RESULTS AND DISCUSSION}

Antimicrobial activity of the plant extracts are shown in Table 1. The result shows that the plant extracts were effective against both gram positive and gram negative organisms. The highest antimicrobial activity (diameter of zone of inhibition, 30mm) was demonstrated by the acetone extracts of stem bark against Proteus mirabilis while the lowest activity (diameter of zone of inhibition $3 \mathrm{~mm}$ ) was demonstrated by the water extract against Staphylococcus aureus. The root extracts generally showed lower activity against the test organisms compared to the stem bark extracts. That is, the stem bark extracts are more effective than the root extracts. This may be related to the fact that the stem bark was more developed and mature than the root which may contain fewer pigments and other phenolics which have been reported to interfere with the antimicrobial activity of the extracts. 


\begin{tabular}{|c|c|c|c|c|c|c|c|c|c|c|c|}
\hline \multicolumn{12}{|c|}{ Treculia Africana } \\
\hline \multirow[t]{3}{*}{ S/No } & \multirow[t]{3}{*}{ Organism } & & & & \multicolumn{7}{|c|}{ Zone of inhibition (mm) } \\
\hline & & \multicolumn{3}{|c|}{ Stem bark extracts } & \multicolumn{3}{|c|}{ Root extracts } & \multicolumn{4}{|c|}{ Antibiotics } \\
\hline & & WE & $\mathbf{A E}$ & EE & WE & $\mathbf{A E}$ & EE & Cip & ot Am & $\mathrm{Nys}$ & \\
\hline 1. & Escherichia coli & $25 \pm 0.1$ & $25 \pm 0.2$ & $24 \pm 0.1$ & $7 \pm 0.1$ & $10 \pm 0.1$ & $8 \pm 0.1$ & 32 & & $18 \mathrm{NA}$ & A NA \\
\hline 2. & Proteus mirabilis & $24 \pm 0.4$ & $30 \pm 0.4$ & $24 \pm 0.3$ & $5 \pm 0.2$ & $7 \pm 0.2$ & $5 \pm 0.2$ & 30 & & $20 \mathrm{NA}$ & A NA \\
\hline 3. & Pseudomonas aeruginosa & $22 \pm 0.2$ & $24 \pm 0.1$ & $23 \pm 0.2$ & $5 \pm 0.2$ & $8 \pm 0.1$ & $6 \pm 0.3$ & 29 & & & NA NA \\
\hline 4. & Salmonella typhi & $24 \pm 0.3$ & $25 \pm 0.2$ & $24 \pm 0.1$ & $5 \pm 0.1$ & $10 \pm 0.1$ & $8 \pm 0.6$ & 29 & & & NA NA \\
\hline 5. & Salmonella paratyphi & $23 \pm 0.1$ & $25 \pm 0.2$ & $20 \pm 0.1$ & $7 \pm 0.2$ & $11 \pm 0.3$ & $9 \pm 0.5$ & 30 & & & NA NA \\
\hline 6. & Klebsiella sp. & $20 \pm 0.1$ & $20 \pm 0.2$ & $17 \pm 0.1$ & $4 \pm 0.2$ & $10 \pm 0.3$ & $7 \pm 0.2$ & & 31 & $14 \mathrm{NA}$ & $\mathrm{NA}$ \\
\hline 7. & Staphylococcus aureus & $21 \pm 0.2$ & $25 \pm 0.1$ & $22 \pm 0.5$ & $3 \pm 0.1$ & $11 \pm 0.1$ & $9 \pm 0.1$ & 27 & $5 \mathrm{~N}$ & A NA & \\
\hline 8. & Bacillus subtilis & $25 \pm 0.1$ & $26 \pm 0.2$ & $23 \pm 0.3$ & $4 \pm 0.1$ & $9 \pm 0.3$ & $8 \pm 0.6$ & 35 & $25 \mathrm{~N}$ & A NA & \\
\hline 9. & Streptococcus pyogenes & $17 \pm 0.2$ & $22 \pm 0.1$ & $21 \pm 0.1$ & $7 \pm 0.2$ & $13 \pm 0.7$ & $10 \pm 0.2$ & 32 & & 9 NA & A NA \\
\hline 10. & Candida albicans & - & - & - & - & - & - & $\mathrm{NA}$ & & NA 29 & 926 \\
\hline
\end{tabular}

Key: WE=Water extract; $\mathbf{A E}=$ Acetone extract; $\mathbf{E E}=$ Ethanol extract; -=no measurable zone;

$\mathbf{C i p}=$ Ciprofloxacin; $\mathbf{C o t}=$ Cotrimoxazole; $\mathbf{A m}=$ Amphotericin B; $\mathbf{N y s}=$ Nystatin; $\mathbf{N A}=$ Not applicable; Values $(\mathrm{mm})$ are mean \pm standard deviation of two replicates $(\mathrm{n}=2)$.

The demonstration of antibacterial activity against both gram positive and gram negative bacteria may be indicative of the presence of broad spectrum antibiotic compounds (Srinivasan et al., 2001). This will be of immense advantage in fighting the menace of antibiotic refractive pathogens that are so prevalent in recent times. The reason for the differential sensitivity between gram-positive pattern and gram-negative bacterial strains could be ascribed to their morphological differences or adduced to their chemical compositions. Gram-negative bacteria have an outer phospholipids membrane with the structural lipopolysaccharide components, which make their cell wall impenetrable to antimicrobial agents, while the gram-positive bacteria should be more susceptible having only an outer peptidoglycan, which is not effective permeability barrier (Ogbonnia et al., 2008).

Out of the three solvents used for extraction, the acetone extracts showed the highest activity against the test organisms, followed by the ethanol extracts and then water extracts. Solvents have been reported to have the varied capacity to extract different phytochemical constituents depending on their solubility or polarity in the solvent (Marjorie, 1999). Acetone extracts in this study might have had higher solubility for more phytochemical constituents, consequently the highest antibacterial activity. The antimicrobial activity exerted by the water extracts corroborates the scientific basis for the use of these plants in the traditional treatment of ailments, as most herbalist practice the use of water as solvent in which the decoctions are prepared. None of the plant extracts evaluated showed antimycotic activity against Candida albicans at the tested concentrations.
The minimum inhibitory concentration (MIC) and minimum bactericidal concentration (MBC) are shown in Table 2. Staphylococcus aureus had the highest MIC $(21 \mathrm{mg} / \mathrm{ml})$ and MBC $(17.5 \mathrm{mg} / \mathrm{ml})$, while the lowest MIC of $6 \mathrm{mg} / \mathrm{ml}$ was demonstrated by Salmonella paratyphi and Bacillus subtilis respectively. Salmonella typhi had MIC and MBC values of $10 \mathrm{mg} / \mathrm{ml}$ for the stem bark extracts. The MIC and MBC values were generally lower for the root extracts against the test organisms compared to those of the stem bark extracts. The highest MIC and MBC values of Staphylococcus aureus is an indication that either the plant extracts are less effective on some gram positive bacteria or that the organism has the potential of developing antibiotic resistance, while the low MIC and MBC values for other bacteria is an indication of the efficacy of the plant extract. The demonstration of broad spectrum of antibacterial activity by Treculia africana may help to discover newer classes of antimicrobial drugs.

The influence of temperature and $\mathrm{pH}$ on the plant extracts showed that varied temperature of $4,30,60$ and $100^{\circ} \mathrm{C}$ had no effect on the antimicrobial activity of the extracts (Figure 1), but the activity slightly increased at acidic $\mathrm{pH}(2-6)$ whereas, at alkaline $\mathrm{pH}$ the activity of the plant extracts decreased (Figure 2). The temperature resistance may be an indication that the phytochemical constituents is able to withstand higher temperatures, thus explaining the usage of these plant parts at high temperature using boiling, as practiced traditionally. The antibacterial activity of the extracts slightly increased at acidic $\mathrm{pH}$. This increase may be attributed to the corrosive/toxic effect of acids combined with the antimicrobial constituents of the extracts. Increase in activity of phytochemical 
constituents in the presence of acidic medium has earlier been reported (Molan, 1992). The local application of these plants involves the addition of high doses of potash which is a strong basic salt, and for the fact that the activity of the extracts reduced at alkaline $\mathrm{pH}$ in this study, may explain why the plant concoction is taken for longer period of time before any curative effect is noticed

Table2: Minimum Inhibitory Concentration (MIC) and Minimum Bactericidal

Concentration (MBC) of ethanolic extracts of Treculia africana

\begin{tabular}{|c|c|c|c|c|c|}
\hline S/No. & Organism & $\begin{array}{l}\text { Stem bark } \\
\text { extract }\end{array}$ & & & $\begin{array}{l}\text { Root } \\
\text { extracts }\end{array}$ \\
\hline & & $\begin{array}{l}\text { MIC } \\
(\mathrm{mg} / \mathrm{ml})\end{array}$ & $\begin{array}{l}\text { MBC (mg/ml) } \\
(\mathrm{mg} / \mathrm{ml})\end{array}$ & MIC & $\begin{array}{l}\mathrm{MBC} \\
\mathrm{mg} / \mathrm{ml})\end{array}$ \\
\hline 1. & Escherichia coli & $15.5 \pm 0.23$ & $15.0 \pm 0.33$ & $\begin{array}{l}18.0 \pm 0 \\
.23\end{array}$ & $\begin{array}{l}18.0 \pm 0.0 \\
3\end{array}$ \\
\hline 2. & $\begin{array}{l}\text { Proteus } \\
\text { mirabilis }\end{array}$ & $15.0 \pm 0.18$ & $21.0 \pm 0.28$ & $\begin{array}{l}20.0 \pm 0 \\
.33\end{array}$ & $\begin{array}{l}20.0 \pm 0.1 \\
3\end{array}$ \\
\hline 3. & $\begin{array}{l}\text { Pseudomonas } \\
\text { aerugenosa }\end{array}$ & $14.0 \pm 0.24$ & $14.0 \pm 0.25$ & $\begin{array}{l}18.0 \pm 0 \\
.27\end{array}$ & $\begin{array}{l}20.0 \pm 0.0 \\
9\end{array}$ \\
\hline 4. & Salmonella typhi & $10.0 \pm 0.23$ & $10.0 \pm 0.13$ & $\begin{array}{l}15.0 \pm 0 \\
.21\end{array}$ & $\begin{array}{l}15.0 \pm 0.1 \\
9\end{array}$ \\
\hline 5. & $\begin{array}{l}\text { Salmonella } \\
\text { paratyphi }\end{array}$ & $8.0 \pm 0.25$ & $8.0 \pm 0.19$ & $\begin{array}{l}15.0 \pm 0 \\
.19\end{array}$ & $\begin{array}{l}15.0 \pm 0.0 \\
3\end{array}$ \\
\hline 6. & Klebsiella spp. & $8.0 \pm 0.19$ & $8.0 \pm 0.17$ & $\begin{array}{l}10.0 \pm 0 \\
.19\end{array}$ & $\begin{array}{l}10.0 \pm 0.5 \\
3\end{array}$ \\
\hline 7. & $\begin{array}{l}\text { Staphylococcus } \\
\text { aureus }\end{array}$ & $6.0 \pm 0.16$ & $20.0 \pm 0.28$ & $\begin{array}{l}20.0 \pm 0 \\
.02\end{array}$ & $\begin{array}{l}20.0 \pm 0.3 \\
3\end{array}$ \\
\hline 8. & Bacillus subtilis & $8.0 \pm 0.28$ & $8.0 \pm 0.22$ & $\begin{array}{l}18.0 \pm 0 \\
.20\end{array}$ & $\begin{array}{l}18.0 \pm 0.2 \\
0\end{array}$ \\
\hline 9. & $\begin{array}{l}\text { Streptococcus } \\
\text { pyogenes }\end{array}$ & $10.5 \pm 0.21$ & $12.5 \pm 0.25$ & $\begin{array}{l}15.0 \pm 0 \\
.20\end{array}$ & $\begin{array}{l}15.0 \pm 0.2 \\
3\end{array}$ \\
\hline 10. & $\begin{array}{l}\text { Candida } \\
\text { albicans }\end{array}$ & - & - & - & - \\
\hline
\end{tabular}

: - = no measurable zone; Values $(\mathrm{mg} / \mathrm{ml})$ are mean \pm standard deviation of two replicates $(\mathrm{n}=2)$

The phytochemical constituents of the plant extracts consisted of glycosides, anthraquinone, free aglycone, saponin, steroids, and polyphenols (Table 3). Phytochemical constituents such as anthraquinone, flavonoids, alkaloids and several other aromatic compounds are secondary metabolites of plants that serve as defense mechanisms against predation by many microorganisms, insects and herbivores (Lutterodt et al., 1999; Marjorie, 1999). Perhaps, this explains the antimicrobial potency of the root and stem bark extracts of Treculia africana.

Therefore, this under-utilized plant need to be further studied to find out the bioactive natural compounds that would facilitate and open up new pharmacological discoveries that may lead to synthesis of a more potent drug with little or no adverse effect.

Table 3: Phytochemical constituents of the hydro/acetone/ethanol

\begin{tabular}{|c|c|}
\hline Phytochemical & Availability \\
\hline Alkaloids & - \\
\hline Cardiac glycosides & + \\
\hline Anthraquinone glycoside & ++ \\
\hline Free aglycone & + \\
\hline Saponin glycosides & +++ \\
\hline Steriodal nucleus & ++ \\
\hline Polyphenols & + \\
\hline Flavonoids & - \\
\hline
\end{tabular}

Key: $-=$ Not available,$+=\overline{\text { slightly available },++=\text { fairly available }}+++=$ abundantly available 


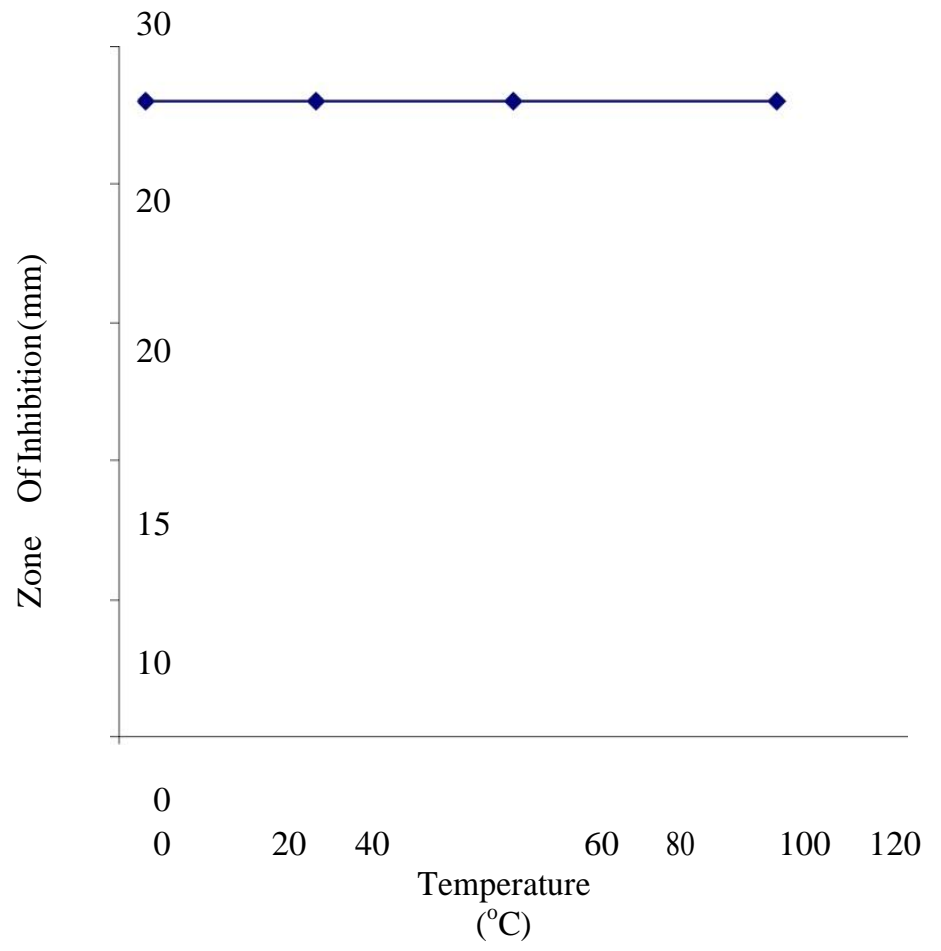

Fig 1: Effect of temperature on antimicrobial activity of Treculia africana

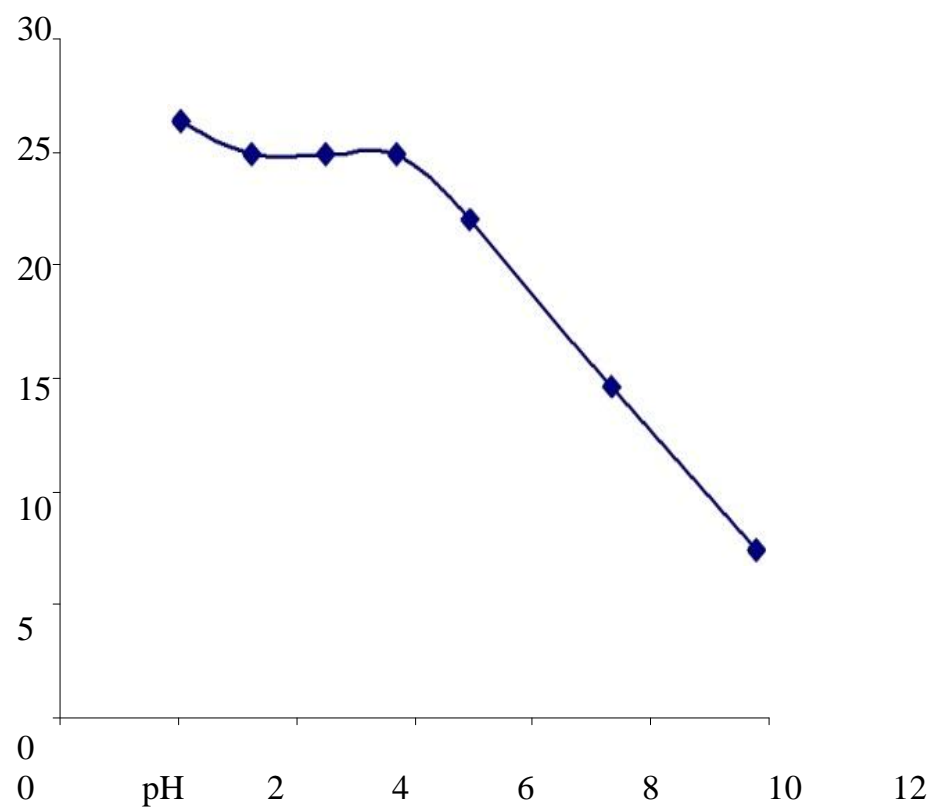

Fig 2: Effect of $\mathrm{pH}$ on antimicrobial activity of Treculia africana

REFERENCES

Aida P., Rosa V., Blamea F., Tomas A. and
Salvador C. (2001). Paraguyan plants used in traditional medicine. Short communicaton. J 
Ethnopharm.16: 93-98.

Bibitha B., Jisha V.K., Salitha C.V., Mohan S. and Valsa A.K. (2002). Antibacterial activity of different plant extracts. Short Communiaction. Indian J Microbiol. 42: 361-363.

Eaton C.D. (1989). Laboratory investigations in organic chemistry. McGraw- Hill, New York, USA.

Farnsworth R.N. (1966). Review on biological and phytochemical screening of plants. J Pharm Sci . 55: 225-276.

Harborne J.B. (1998). Phytochemical methods: A guide to modern techniques of plant analysis $3^{\text {rd }}$ edn. Chapman and Hall, London.

Houghton P.J., Raman A. (1998). Laboratory handbook for fractionation of natural extracts. Chapman and Hall, London.

Lutterodt G.D., Ismail A., Basheer R.H. and Baharudin H.M. (1999). Antimicrobial effects of Psidium guajava extracts as one mechanism of its antidiarrhoeal action. Malaysian J Med Sci. 6: 17-20.

Maghrani M., Zeggwah N., Michel J. and Eddouks, M. (2005). Antihypertensive effect of Lepidium sativum in spontaeneously hypertensive rats. J Ethnopharm. 102:193-197.

Marjorie M.C. (1999). Plant products as antimicrobial agents. Clin Microbiol Rev.12: 564-582 .

Molan P.C. (1992). The antibacterial activity of honey. Bee World.73:59-76.

Njoku H.O., Ibe S.N., Odu N.N., Oyeyipo O.O. (2013). Processing and characteristics of African breadfruit tempe-fortified lafun. Nat and Sci.11: 116-120.

S.O., Enwuru N.V., Onyemenem E.U., Oyedele G.A. and Enwuru C.A. (2008). Phytochemical evaluation and antibacterial profile of Treculia africana Decne bark extract on gastrointestinal bacterial pathogens. Afric J Biotech. 7: 13851389.
Ogbonnia S.O., Odimegwu J.I., Enwuru V.N. (2008) Evaluation of hypoglycaemic and hypolipidaemic effects of aqueous ethanolic extracts of Treculia africana Decne and Bryophyllum pinnatum Lam. and their mixture on Streptozotocin (STZ)induced diabetic rats. Afric J Biotech. 7: 25352539.

Oyeyipo O.O. (2011). Studies on lafun fortified with African breadfruit tempeh, MSc thesis, University of Port.

Oyeyipo O.O., Ibe, S.N. and Njoku, H.O. (2012). Evaluation of lafun fortified with African breadfruit tempe. A paper presented at the proceedings of the $16^{\text {th }}$ Annual world congress of food science and technology, Brazil.

Oyeyipo O.O., Iwuji C.A. and Nworgu U.G. (2012). Sensory Evaluation of a Vegetable Yoghurt-like Product from the African Breadfruit (Treculia africana) Seeds. Intl J Food Res. 2: 11-16.

Predrag L., Hui S., Uri C., Hasswan A., Arieh B. (2005). The effects of aqueous extracts prepared from leaves of Pistacia lentiscus in experimental liver disease. J Ethnopharm.100: 198-204.

Silva L.G., Lee I.S., Kinghorn D.A. (1993). Special problems with the extraction of plants. In: Methods in Biotechnology Vol 4. Natural product isolation. Cannell JPR (ed) Humana Press Inc., Totowa, New Jersey, USA pp. 329363.

Srinivasan D., Perumalsamy L.P., Nathan S., Sures T. (2001). Antimicrobial activity of certain Indian medicinal plants used in folkloric medicine. J Ethnopharm. 94: 217-222. 